\title{
Extracutaneous glomus tumour of the trachea
}

\author{
Daniel Brzeziński ${ }^{1}$, Mariusz Piotr Łochowski ${ }^{1}$, Dorota Jesionek-Kupnicka², Józef Kozak ${ }^{1}$ \\ ${ }^{1}$ Thoracic Surgery Clinic, Provincial Specialist Hospital, Lodz, Poland \\ ${ }^{2}$ Medical University of Lodz, Poland
}

Kardiochirurgia i Torakochirurgia Polska 2015; 12 (3): 269-271

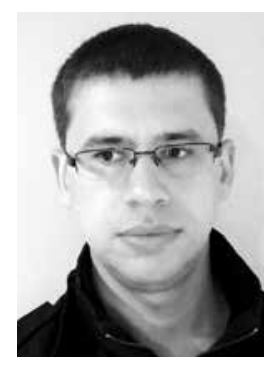

\begin{abstract}
A 38-year-old man presenting expiratory stridor and high-grade dyspnoea was admitted to hospital in Lodz in February 2013. Chest radiographs and computed tomography scans showed a solid lesion in the upper part of the trachea occluding $85 \%$ of the airway lumen. A segmental resection of the trachea with a subsequent end-to-end anastomosis was performed. Histopathology showed an extracutaneous glomus tumour. There were no postoperative complications. Tracheal resection is the primary curative method in cases of this rare tumour.
\end{abstract} Key words: glomus tumour, trachea, bronchoscopy.

\section{Introduction}

According to the World Health Organisation (WHO) classification, a glomus tumour is a mesenchymal neoplasm composed of cells resembling modified smooth muscle cells of the normal glomus body [1] and, classifiably, belongs to the group of pericytic (perivascular) tumours (together with only one other tumour called myopericytoma). Glomus bodies in the body are responsible for blood flow regulation and temperature control on the skin surface.

The origin of extracutaneous glomus tumours has been considered to be ectopic glomus cells or proliferation of undifferentiated perivascular cells [2]. A little more than 20 cases of the tracheal glomus tumours have been described in literature, mostly in the mid or lower parts of the trachea. We present a case of a 38-year-old male with the tumour located in the upper part of the trachea.

\section{Material and methods}

A 38-year-old man was admitted to the Copernicus Memorial Hospital in Lodz with obstructive symptoms in February 2013. He had a 15-pack-year history of smoking and presented progressive weakness and loss of exercise capacity during the whole preceding year. The patient also noticed frequent tracheal and bronchial infections. Physical examination showed expiratory stridor and high-

\section{Streszczenie}

W pracy przedstawiono przypadek mężczyzny, 38 lat, który zgłosit się do szpitala w Łodzi w lutym 2013 r. z wydechowym stridorem i silną dusznością. Rentgenogram i tomografia komputerowa klatki piersiowej wykazały obecność litej zmiany w tchawicy pacjenta, blokującej 85\% światła drogi oddechowej. Wykonano resekcję odcinka tchawicy i zespolenie koniec do końca. W badaniu histopatologicznym zmiana została sklasyfikowana jako extracutaneous glomus tumour. Okres pooperacyjny był niepowikłany. Resekcja tchawicy jest podstawową metodą leczenia tego rzadkiego guza.

Słowa kluczowe: przyzwojak, tchawica, bronchoskopia.

grade dyspnoea. Preoperative chest radiographs and computed tomography series revealed a solid $16 \times 18 \times 8 \mathrm{~mm}$ lesion in the upper part of the trachea. The tumour was limited only to the wall of the trachea. Subsequently, we performed a flexible bronchoscopy, which confirmed and demonstrated a polypoid tumour arising from the rightposterior wall of the 2 and 3 cartilages in the subglottic area (Fig. 1A). The lesion occluded approximately $85 \%$ of the airway lumen.

Histopathologically, the tumour was located in the mucosa of the trachea, covered with squamous epithelium without atypia with focal ulceration, well circumscribed without infiltration or satellite nodules. It was composed of slot-like and cavernous vessels with flattened endothelial cells (Fig. 2A and B). Around the vessels were sheets of regular, oval glomus cells with abundant lightly eosinophilic cytoplasm and distinct cellular borders (Fig. 2B). Immunohistochemically, the tumour cells were strongly positive for $\alpha$-smooth muscle actin (SMA, DAKO, cytoplasmatic reaction) (Fig. 2C) and vimentin (DAKO), and negative for S-100 protein (antibody anti S-100p, DAKO), wide-spectrum cytokeratins (antibody anti CKAE1/AE3, DAKO), and synaptophysin. There were only a few mitotic figures; the cell proliferation determined by MIB-1 (Ki-67, DAKO) was very low (less than $1 \%$ of cells). 

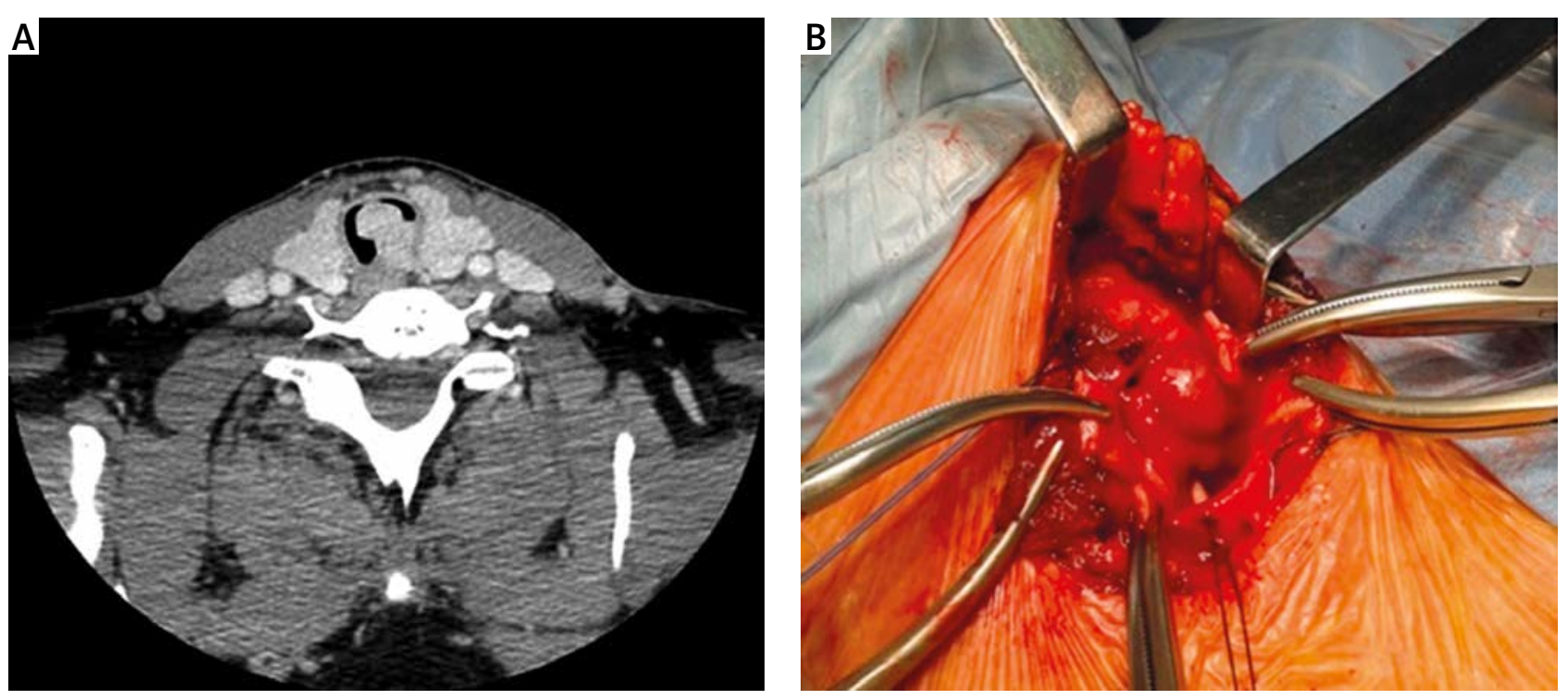

Fig. 1. A) Computerized tomography scan showing the narrowed lumen of the trachea. B) A view of the tumour during the operation

A
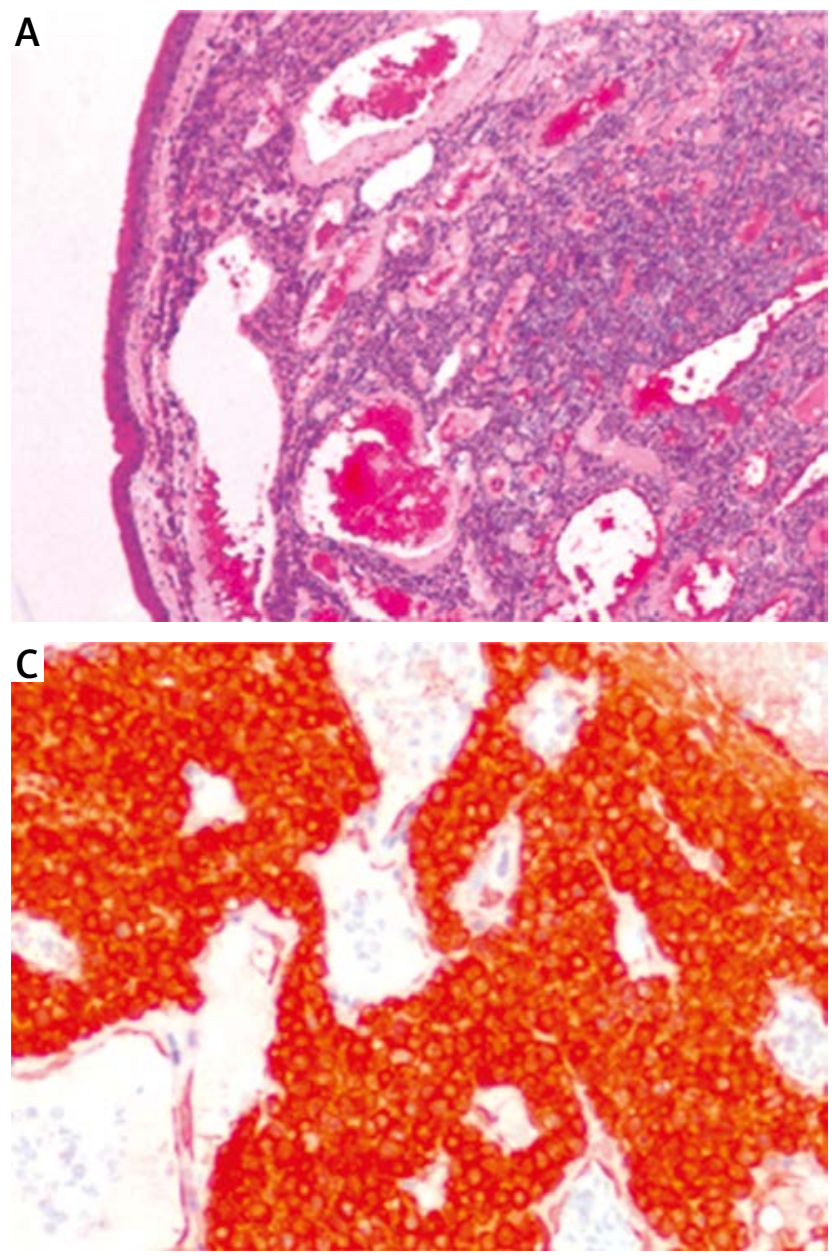

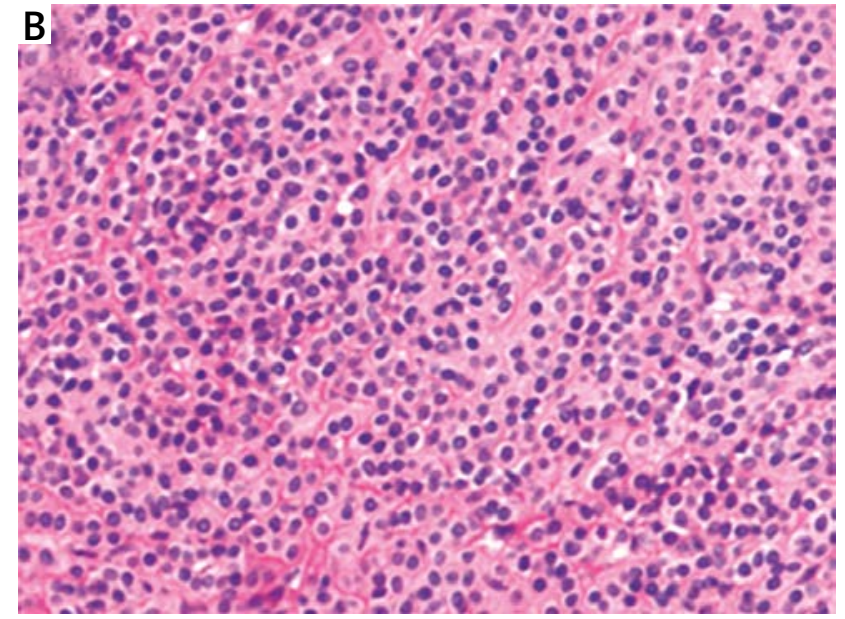

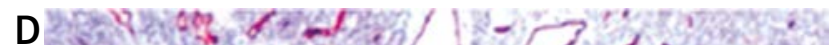

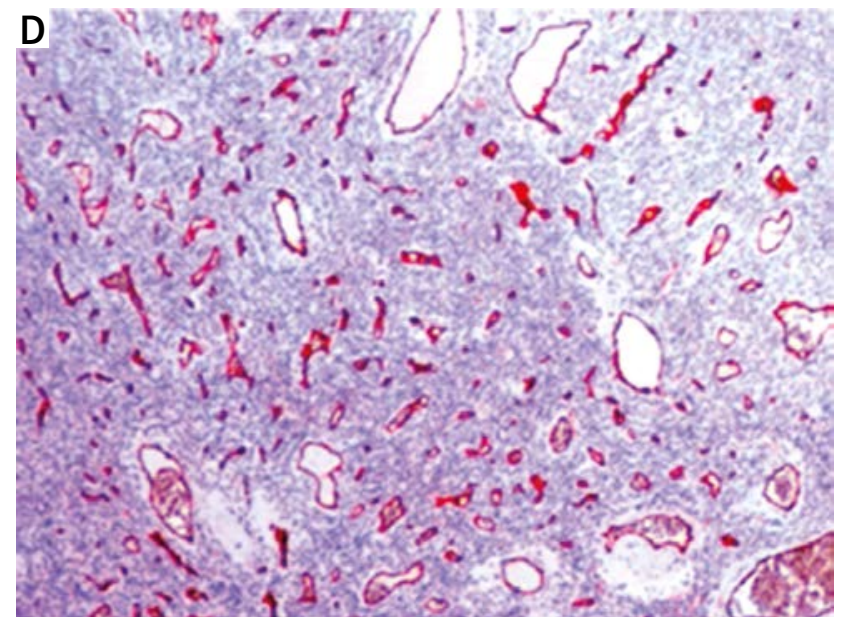

Fig. 2. Histopathological picture of the extracutaneous glomus tumour in the trachea. A) Intramucosal tumour with vascular and solid areas composed of sheets of glomus cells growing in a circumferential perivascular fashion; HE $\times 40$. B) A sheet of oval cells without atypia with abundant cytoplasm; mitotic figures are very scarce; $\mathrm{HE} \times 200$. C) The main hallmark of glomus cells is positive immunohistochemical reaction with antibody anti smooth muscle actin (SMA) (DAKO); $\times 200$. D) The vascular structure of the tumour is emphasised by immunohistochemical reaction with CD34 (DAKO); × 40 


\section{Results}

We decided to perform a transverse cervical incision (Fig. 1B). The tumour was surgically resected by means of a segmental resection of the trachea within confirmed negative margins and an end-to-end anastomosis. There were no postoperative complications. After six days a flexible bronchoscopy was performed to check the suture line and the patient was discharged from hospital.

\section{Discussion}

Glomus tumours are uncommon neoplasms, constituting less than $2 \%$ of all soft-tissue tumours. This kind of tumour was first described by Masson in 1924. Since then, sporadic reports of varying types and locations have appeared in the literature.

Glomus tumours can be solitary or multicentric, and are most commonly found in the subungual area of the finger, the other sites being the palm, wrist, forearm, and foot. Unusual sites have included muscles, tendons, ligaments, periosteum, and visceral organs, such as the stomach, mesentery, genitals, mediastinum, heart, lung, and trachea $[3,4]$. Glomus tumours of the trachea are more common in males than in females [2:1]. The average patient age is 45 years old; the youngest being 10 years old. The tumour size ranges from $1.2 \mathrm{~cm}$ to $4.5 \mathrm{~cm}$. The most common symptoms are dyspnoea, haemoptysis, cough, chest pain, stridor, and hoarseness, but some can also be asymptomatic $[3,5]$.

Due to the histopathological pattern of growth, glomus tumours are divided into solid glomus tumours, glomangiomas and glomangiomyomas, depending on the dominant component being glomus cells, vascular structures, and smooth muscles, respectively. We categorised our case as a solid glomus tumour because the main component was sheets of glomus cells as opposed to a glomangioma in which the main component is vascular structures, with only several layers of glomus cells. A glomangiomyoma has a distinct histopathological picture with elongated smooth muscle cells; in the so-called "glomangiopericytoma" the main feature is haemangiopericytoma-like vasculature [1].

The differential diagnosis mainly took into account a haemangiopericytoma, eccrine spiradenoma, and melanocytic nevus.

Tracheal resection with primary reconstruction should be performed as a treatment of choice. Alternative therapies such as laser surgery with subsequent radiation, electrocautery, and mechanical debulking should be performed only in inoperable patients.

Results are good for complete resections. There were no recurrences after this procedure.

\section{Disclosure}

Authors report no conflict of interest.

\section{References}

1. Folpe AL. Glomus tumours. In: World Health Organization classification of tumours. Pathology and genetics of tumours of soft tissue and bone. Fletcher CDM, Unni KK, Mertens F (eds.). IARC Press, Lyon 2002; pp. 135-139.

2. Sangüeza OP, Requena L. Glomus tumors. In: Pathology of vascular skin lesions: clinicopathologic correlations. Sangueza OP, Requena L (eds.). Humana Press Inc., Totowa 2003; pp. 198-207.

3. Sakr L, Palaniappan R, Payan MJ, Doddoli C, Dutau H. Tracheal glomus tumor: A multidisciplinary approach to management. Respir Care 2011; 56: 342-346.

4. Takahashi N, Oizumi H, Yanagawa N, Sadahiro M. A bronchial glomus tumor surgically treated with segmental resection. Interact Cardiovasc Thorac Surg 2006; 5: 258-260.

5. Parker KL, Zervos MD, Donington JS, Shukla PS, Bizekis CS. Tracheal glomangioma in a patient with asthma and chest pain. J Clin Oncol 2010; 28: e9-e10. 